УДК [94::264-931:726.8:728.98](47)“18”

DOI: $10.17223 / 22220836 / 40 / 20$

\title{
Д.А. Будюкин
}

\section{УСЫПАЛЬНИЦЫ-ОРАНЖЕРЕИ В РОССИИ ХІХ ВЕКА ${ }^{1}$}

\begin{abstract}
В России ХІХ в. известны две усыпальницы-оранжереи - принцев Ольденбургских в Троице-Сергиевой пустыни под Санкт-Петербургом и графов Келлеров в усадьбе Сенницы Московской губернии. Обе аристократические семьи, изначально лютеранские, стали межконфессиональными в результате перехода некоторых их членов в православие. В обоих случаях строчтельство усыпальнии связано с погребением девочки или юной девушки. По-видимому, эти сооружения не вызывали удивления современников. Анализ показывает, что создание таких усыпальнии уникально совмещением традиционных представлений, связывающих дерево с захоронением, с престижным погребением внутри часовни, позволяя преодолеть конфессиональные гранищы и рамки династического статуса.

Ключевые слова: оранжерея, погребальная часовня, похоронные практики, межконфессиональная семья, аристократия, Россия XIX в.
\end{abstract}

В России XIX в. известны два случая постройки крайне необычного погребального сооружения - усыпальницы-оранжереи. Первый из этих случаев имел место в семье принцев Ольденбургских, происходивших из общего линьяжа с Гольштейн-Готторпской ветвью династии Романовых (ее основатель Христиан Август был братом деда Петра III) [1. С. 507]. Российская линия этой фамилии происходит от его внука принца Георга (Георгия Петровича), женатого на великой княжне Екатерине Павловне. Принц был ревностным лютеранином и отклонил предложение Александра I дать его старшему сыну Александру титул великого князя при условии крещения в православие [2. С. 151]. Его детям от брака с великой княжной Екатериной Павловной по брачному договору следовало наследовать вероисповедание отца [Там же. C. 99]. Похоронили умершего в 1812 г. принца Георгия в лютеранской Петропавловской церкви (Петрикирхе) на Невском проспекте Петербурга. В 1826 г. по желанию его отца он был перезахоронен в мавзолее герцогов Ольденбургских на кладбище Святой Гертруды в Ольденбурге [Там же. С. 150$151]$.

Принц Петр, сын Георгия и Екатерины Павловны, после смерти отца и брата в 1829 г. поступил на российскую службу, сохранив лютеранское вероисповедание. В 1837 г. в Висбадене он вступил в брак с принцессой Терезией Нассауской, тоже лютеранкой [Там же. С. 198, 228]. Однако местом погребения его семьи, первая смерть в которой (дочери Марии) наступила 29 декабря 1842 г., был избран православный монастырь - Троице-Сергиева Приморская пустынь в Стрельне под Петербургом [3. Т. 3. С. 309], известный как одно из двух (тогда) наиболее престижных мест захоронения в столице, а также тем, что на его кладбище было погребено много иноверцев и иностранцев [4.

${ }^{1}$ Статья подготовлена при поддержке гранта РФФИ № 18-411-480001 «Трансформация повседневной мифологии семейной памяти в культурном ландшафте современной Центральной России: научная аналитика и региональные социокультурные практики». 
C. 204]. Принцесса Терезия, умершая в 1871 г., также была похоронена в этом монастыре, где уже были могилы ее детей: дочерей Марии, Екатерины (ум. 1866) и сына Георгия (ум. 1871) [2. С. 328]. Принц Петр Георгиевич скончался 2 мая 1881 г. и был похоронен рядом с ней.

Над могилами Ольденбургских была сооружена необычная часовняусыпальница, описанная в майских номерах газеты «Голос» в связи с похоронами принца П.Г. Ольденбургского 9 мая 1881 г.: «Над усыпальницей воздвигнут очень изящный стеклянный павильон, который можно назвать оранжереей. Могила почившего принца находится на правой стороне в крайнем углу рядом с могилой его супруги. На левой стороне погребены дети их высочеств... Между родителями и детьми большой деревянный крест с художественным изображением распятого Христа. Перед ним теплится лампада. Направо при входе в этот надгробный цветник погребены внуки принца младенцы Олег и Петр, графы Остернбург. Пол устлан коврами» [Там же. C. 330]. Сохранилась также находящаяся в собрании кантональной библиотеки Лугано (Швейцария) фотография «на память» возле усыпальницы, сделанная в 1871 г. во время церемонии погребения (вероятно, принца Георгия Петровича или принцессы Терезии) Иваном Бианки [5. С. 118, 144].

Принцы Николай и Константин Петровичи, вступившие в морганатические браки с православными дворянками, и сами перешли в православие [2. C. 485]. Они и сохранившая принадлежность к лютеранству принцесса Терезия Петровна, супруга князя Георгия Максимилиановича Романовского, герцога Лейхтенбергского, также были похоронены в родовой усыпальнице в Сергиевой пустыни [3. Т. 2. С. 638; Т. 3. С. 309]. Там же упокоились и трое умерших до революции графов фон Остернбург, детей принца Николая Петровича Ольденбургского от морганатического брака с Марией Ильиничной Булацель, православного исповедания [3. Т. 3. С. 330-331]. Всего их было четверо: Александра (1864-1952), Петр (1866-1867), Ольга (а не Олег) (18681869), Вера (1871-1888) [1. С. 511].

Все последующие представители российской ветви принцев Ольденбургских умерли и были похоронены уже в эмиграции. Что касается их вероисповедания, то при вступлении принца Александра Петровича в брак с княжной Евгенией Максимилиановной Романовской, герцогиней Лейхтенбергской, было специально оговорено несогласие великого герцога Ольденбургского как главы династии на воспитание детей от этого союза в православной вере [2. С. 558]. Однако их сын принц Петр в 1901 г. перешел в православие в связи с предстоящим браком с сестрой Николая II Ольгой Александровной, лишившись при этом права наследования в Ольденбургском герцогстве [Там же. С. 712]).

Другой случай постройки подобного сооружения связан с семьей графов Келлеров. Барон Людвиг Христофор Келлер, в 1789 г. получивший прусский титул графа, был женат на сестре российского фельдмаршала князя Петра Витгенштейна. Одна из его дочерей была замужем за князем Иваном Ивановичем Барятинским, а сын Теодор (в России Федор Федорович) вступил в российское подданство и женился на графине Софье Михайловне Борх [6. Ч. 3. С. 156-157]. Внуком Федора Федоровича был граф Федор Эдуардович Келлер (1850-1904), один из самых известных боевых генералов своего времени. Он женился на княжне Марии Александровне Шаховской, внучке гра- 
фа Михаила Юрьевича Виельгорского, и получил за ней в приданое усадьбы Сенницы в Зарайском уезде Рязанской губернии. Дети от этого брака в соответствии с законом воспитывались в православной вере, в то время как сам граф Келлер до конца жизни остался лютеранином.

В Сенницах была построенная в 1709 г. князем М.П. Гагариным Вознесенская церковь с нижним храмом-усыпальницей Гагариных во имя апостола Матфея [7. С. 499]. Князья Гагарины были предками Марии Келлер (Шаховской), тем не менее в 1894 г. Ф.Э. Келлер заказал архитектору Н.В. Султанову проект «железной усыпальницы-оранжереи» в Сенницах в связи со смертью девятилетней дочери Марии, умершей от травм, полученных при катании с ледяной горки [Там же. С. 504]. Усыпальница представляла собой обширное сооружение, выполненное из металлического каркаса. Сплошное остекление давало необходимое для экзотических растений освещение. Вход был выполнен из кирпича, рядом находилась отопительная печь [8. С. 543]. Часовня была подробно описана впоследствии в связи с похоронами в ней самого Келлера, погибшего на русско-японской войне. «В одном из самых уютных уголков парка высится стеклянная галерея, сооруженная наподобие оранжереи. Это своеобразное сооружение и предназначается быть семейной усыпальницей графов Келлер. В этой „часовне-теплице“ уже покоится прах безвременно скончавшейся дочери графа Феодора Эдуардовича. Останки отца-героя лягут рядом с могилой дочери... Часовня уставлена тропической зеленью. В передней стене распятие с лампадой перед ним, тесно обвитое темной зеленью плюща и окаймленное розами. В обстановке этой усыпальницы есть что-то неожиданно-радостное, чуется какая-то светлая христианская надежда, не затмеваемая черной тенью смерти» [9. С. 52-53]. В 1911 г. в часовне-оранжерее был похоронен третий член семьи Келлеров - умерший 30 октября от дифтерии малолетний сын тогдашнего владельца усадьбы графа Александра Федоровича Федор [7. С. 506]. Руины усыпальницы Келлеров, в отличие от аналогичного сооружения Ольденбургских, сохранились [10. C. 139].

Интересно, что усыпальницы-оранжереи, по-видимому, не казались современникам чем-то исключительным и привлекали не так много внимания. Содержательные упоминания рассмотрены нами выше, и, несмотря на высокое положение и широкую известность рода Ольденбургских, их очень немного. Находившийся на российской службе прусский офицер граф Рихард фон Пфейль отмечает, что «хотя герцог <принц Петр> принадлежал к лютеранскому вероисповеданию, но хоронили его по православному обряду, и даже евангелическая часовня, находившаяся во дворце, была на время похорон закрыта» [11. С. 285]; об усыпальнице-оранжерее ни слова. Е.А. Нарышкина, описывая в воспоминаниях похороны принца П.Г. Ольденбургского, на которых она присутствовала, указывает только, что они «были в Сергиевской пустыни», не упоминая ни вероисповедание покойного, ни необычную усыпальницу [12. С. 294, 459]. Хотя сестра Ф.Э. Келлера графиня Мария Клейнмихель оставила воспоминания, в их тексте, в целом малодостоверном и не изобилующем бытовыми подробностями, повествование о брате, с которым она была «в очень близких отношениях» [13. С. 118], занимает всего две страницы, а его усыпальница не упоминается вовсе. В наши дни несохранившаяся усыпальница Ольденбургских также не вызывает удивления у ав- 
тора описания Троице-Сергиевой пустыни, оказываясь в одном ряду с таким распространенным типом усыпальницы, как ротонда: «территорию обители украшали изящной архитектуры ротонды и оранжереи-усыпальницы: ротонда-усыпальница семьи Толстых, оранжерея-усыпальница семьи принцев Ольденбургских» [14].

Ю.Р. Савельев предполагает, что к созданию данного типа усыпальниц были более склонны дворянские семьи, имевшие западноевропейское происхождение и более свободно трактовавшие мемориальную идею [8. С. 541]. Вероятно, западноевропейское, а более конкретно - немецкое происхождение имеет в данном случае определенное значение, как и принадлежность к протестантизму. Тем не менее нет никаких данных о том, что идея усыпальницыоранжереи заимствована из Западной Европы либо связана с протестантским вероисповеданием, и не совсем понятна связь между западноевропейским происхождением и свободной трактовкой мемориальной идеи. На наш взгляд, в данном случае важнее то, что обе семьи в результате браков с православными и переходов в православие стали межконфессиональными, а часть потомков принцев Ольденбургских в результате морганатических браков утратила династический статус. Следовательно, усыпальницы-оранжереи объединяли умерших членов семей независимо от различий в вероисповедании и статусе. Это особенно заметно в связи с тем, что Келлеры не использовали существовавшую в Сенницах церковь-усыпальницу - возможно, именно потому, что ее использование разделило бы захоронения членов их семьи по конфессиональному признаку. При этом в обоих случаях строительство усыпальниц-оранжерей связано с погребением девочки или юной девушки.

Вписывая усыпальницы-оранжереи в контекст традиционных представлений и, в частности, погребальных обычаев, мы можем отметить, что свойственные оранжерее свет и тепло противоположны ассоциируемым со смертью тьме и холоду. Радостную и светлую христианскую надежду, не затмеваемую черной тенью смерти, чувствует современник при виде усыпальницы Келлеров [9]. Что касается связи дерева и захоронения в целом, то она встречается настолько часто, в столь различных культурах и до такой степени разнообразна, что в статье можно рассмотреть только наиболее существенные в контексте изучаемого феномена ее аспекты. Так, захоронение костей и вырастающее из трупа волшебное дерево - распространенный сказочный мотив, отражающий важную для исследования коммеморации роль дерева как физической манифестации субъекта [15. Р. 245] и описанный В.Я. Проппом, который связывает куст или дерево, вырастающее из могилы, с магией, обеспечивающей плодородие садов [16. С. 6, 17]. М.А. Прусова отмечает, что «защита со стороны природы, помимо недоступности места погребения, осуществляется деревьями, создающими тень... Способ защиты сенью (тенью) деревьев, конечно, самый распространенный, и прежде всего потому, что это деталь реального пейзажа: на кладбище сажают деревья... Для выражения скорби, причем скорби красивой и торжественной, служат вечнозеленые хвойные растения» [17. С. 120-125]. В данном случае представляется существенным, что экзотические растения в теплице тоже вечнозеленые.

Роль растений как средства личной коммеморации изучена еще недостаточно [15. Р. 243-244], однако можно привести несколько примеров, связан- 
ных с русскими и территориально и / или культурно близкими к ним этносами. На Европейском Севере России повсеместно встречаются кладбищенские ритуальные деревья-знаки (карсикко), одна из функций которых - обозначить дорогу душе умершего на тот свет и оградить живых от мертвых в этом мире [18. С. 209]. Как пишет А.П. Конкка далее, по поводу других проявлений темы «дерево у могилы» следует, помимо общих тенденций погребения в рощах и вырубания карсикко в них, отметить древний обычай - захоронение под деревом [Там же. С. 210]. В отношении карельских захоронений отмечается особая роль ели [Там же. С. 216].

На востоке Украины отмечалась практика захоронения покойниковпростолюдинов «в гумнах под грушками», отношение к которой представителей церкви было презрительно-снисходительным [19. С. 161]. В Путивльском районе Сумской области у горюнов (особой этнографической группы русского населения) практика погребения в садах сохранилась почти до наших дней, при этом рассказывают, что местные священники не отказывались участвовать в таких погребениях по просьбе родственников умершего [20. C. 10].

В современной западной культуре на фоне снижения религиозности и роста значимости экологической культуры имеет место возникновение традиции «природного захоронения», наиболее распространенной формой которого является посадка на могиле дерева вместо установления надгробия. Захоронения традиционного типа, в условиях ускорения современной жизни спустя относительно короткий срок уничтожаемые и заменяемые новыми, все в меньшей степени удовлетворяют потребность в «вечной памяти», с которой люди обращаются к циклическому постоянству природы, «экологическому бессмертию». В сравнении с надгробным камнем или плитой живое дерево становится более действенным и эмоциональным мемориальным объектом [15]. Хотя в рамках этой новой традиции нет данных о погребениях в оранжереях, связь между ней и рассматриваемым феноменом очевидна.

Таким образом, создание оранжерей-усыпальниц уникально совмещением древних традиционных представлений, связывающих дерево с захоронением, с характерным для христианской аристократии престижным погребением внутри храма или часовни. Все другие известные примеры связи захоронения с растениями, более тесной, чем обычное присутствие растительности на кладбище, находятся с христианством в сложных отношениях, а нередко и в противостоянии. При этом такой тип надгробного здания позволяет преодолеть конфессиональные границы и рамки династического статуса, труднопреодолимые в случае внутрихрамового погребения, сочетая при этом сохраняющую актуальность дохристианскую традицию с возведением погребального сооружения, отвечающего социальным нормам, аристократическим представлениям о престиже и не противоречащего христианским канонам.

\section{Литература}

1. Семенов И.С. Европейские династии: Полный генеалогический справочник / науч. ред. Е.И. Карева, О.Н. Наумов; вступ. ст. О.Н. Наумов. М. : Энциклопедия, ИНФРА-М, 2006. 1104 с.

2. Анненкова Э.А. Принцессы Ольденбургские. М. : ИД Тончу, 2014. 784 с.

3. Петербургский некрополь: в 4 т. / сост. В.И. Саитов. СПб., 1912-1913.

4. Пыляев М.И. Забытое прошлое окрестностей Петербурга. СПб., 1889. 550 с.

5. Китаев А. Петербург Ивана Бианки. Poste restante. СПб. : Росток, 2015. 168 с.

6. Долгоруков П.В. Российская родословная книга: в 4 ч. СПб., 1854-1857. 
7. Лялин С.П., Минина Е.Л. История усадьбы Сенницы // Русская усадьба: сб. ОИРУ. Вып. 9 (25). М. : Жираф, 2003. С. 498-507.

8. Савельев Ю.Р. Усадьба Сенницы и неизвестный проект Н.В. Султанова // Русская усадьба: сб. ОИРУ. Вып. 7 (23). М. : Жираф, 2001. С. 538-544.

9. Авчинников А.Г. Памяти графа Ф.Э. Келлера. Екатеринослав : Печатня С.П. Яковлева, Б. г. $56 \mathrm{c}$.

10. Чижков А.Б. Подмосковные усадьбы. 3-е изд. М., 2006. 280 с.

11. Пфейль Р. Из воспоминаний графа фон-Пфейля (1881-1889) / пер. с нем. и пересказ А.М. Белова // Исторический вестник. 1908. Т. 114, № 10. С. 278-288.

12. Нарышкина E.A. Мои воспоминания. Под властью трех царей / вступ. ст., подг. текста, пер. и коммент. Е.В. Дружининой. М. : НЛО, 2014. 688 с.

13. Двориовые интриги и политические авантюры. Записки Марии Клейнмихель / сост. В.М. Осин. М. : АСТ, 2013. 448 с.

14. Туркова И.В. Очерк о пустыни // Сайт «Свято-Троицкая Сергиева Приморская мужская пустынь». URL: http://pustin.spb.ru/index.php/istoriya-monastyrya (дата обращения: 27.02.2019).

15. Clayden A., Dixon K. Woodland burial: Memorial arboretum versus natural native woodland? // Mortality. 2007. Vol. 12, № 3. P. 240-260.

16. Пропп В.Я. Сказка. Эпос. Песня / сост., науч. ред., коммент. и указатели В.Ф. Шевченко. М.: Лабиринт, 2001. 368 c.

17. Прусова М.А. Реализация мотива защиты «вечного дома» в русской поэзии первой половины XIX века // Культура народов Причерноморья. 2000. № 15. С. 120-125.

18. Конкка А.П. Дерево у могилы. На кладбищах Северо-восточной Карелии // Вестник Санкт-Петербургского университета. Сер. 2: История. 2007. Вып. 3. Сентябрь. С. 209-216.

19. Замура O. «Великий шаленець»: смерть і смертність в Гетьманщині XVIII ст. Київ : K.I.C., 2014. 240 c.

20. Толстая С.М., Толстая М.Н. Погребения в саду у «горюнов» Сумской области // Живая старина. 2003. № 2. С. 10-13.

Dmitri A. Budiukin, Lipetsk State Technical University (Lipetsk, Russian Federation).

E-mail: boudukin@yandex.ru

Vestnik Tomskogo gosudarstvennogo universiteta. Kul'turologiya i iskusstvovedeniye - Tomsk State University Journal of Cultural Studies and Art History, 2020, 40, pp. 229-235.

DOI: $10.17223 / 2220836 / 40 / 20$

\section{BURIAL CHAPELS IN 19TH CENTURY RUSSIA} ry Russia.

Keywords: glasshouse; burial chapel; funeral practices; interfaith family, aristocracy; $19^{\text {th }}$ centu-

Religious burial structures as places of family memory and religious commemorative practices in interfaith families are of great research interest in the modern science, and it makes the topic of the research actual.

The aim of the research is to review the phenomenon of building the glasshouse burial chapels and to find regularities connected to it.

The research is based upon the study of sources such as descriptions and images of architectural objects, memoirs and journal articles. The research methods of ethnology and anthropology are implied to the material.

There are two glasshouse burial chapels known in $19^{\text {th }}$ century Russia - of Princes of Oldenburg in Holy Trinity-St. Sergius monastery near St. Petersburg and of Counts Keller in Sennitsy manor of Moscow province. Both aristocratic families were of Lutheran origins and became interfaith due to conversion of some their members to Orthodoxy. In both cases the construction of the chapels is connected with the burials of young girls. The buildings seemed to cause no contemporaries' astonishment.

The analysis shows that creation of such burial places is unique because of combination of traditional conceptions connecting tree and burial with prestigious burial inside a chapel, enabling to surmount confessional borders and bounds of dynastic status. All the other examples of burials connected with plants closer than the generic presence of plants in cemeteries, are somehow opposed to Christianity.

\section{References}

1. Semenov, I.S. (2006) Evropeyskie dinastii: Polnyy genealogicheskiy spravochnik [European Dynasties: A Complete Genealogical Reference]. Moscow: Entsiklopediya, INFRA-M. 

Tonchu.

2. Annenkova, E.A. (2014) Printsessy Ol'denburgskie [Princesses of Oldenburg]. Moscow: ID

3. Saitov, V.I. (1912-1913) Peterburgskiy nekropol': v 4 t. [The St. Petersburg Necropolis: in 4 vols]. St. Petersburg: [s.n.].

4. Pylyaev, M.I. (1889) Zabytoe proshloe okrestnostey Peterburga [Forgotten past of the outskirts of St. Petersburg]. St. Petersburg: [s.n.].

5. Kitaev, A. (2015) Peterburg Ivana Bianki. Poste restante [The Petersburg of Ivan Bianki. Poste restante]. St. Petersburg: Rostok.

6. Dolgorukov, P.V. (1854-1857) Rossiyskaya rodoslovnaya kniga: v 4 ch. [Russian genealogical book: in 4 vols]. St. Petersburg: [s.n.].

7. Lyalin, S.P. \& Minina, E.L. (2003) Istoriya usad'by Sennitsy [History of the Sennitsa Estate]. In: Nashchekina, M.V. (ed.) Russkaya usad'ba [The Russian Estate]. Vol. 9(25). Moscow: Zhiraf. pp. 498-507.

8. Saveliev, Yu.R. (2001) Usad'ba Sennitsy i neizvestnyy proekt N.V. Sultanova [The Sennitsa estate and an unknown project by N.V. Sultanov]. In: Nashchekina, M.V. (ed.) Russkaya usad'ba [The Russian Estate]. Vol. 7(23). Moscow: Zhiraf. pp. 538-544.

9. Avchinnikov, A.G. (n.d.) Pamyati grafa F.E. Kellera [In memory of Count F.E. Keller]. Ekaterinoslav: S.P. Yakovlev.

10. Chizhkov, A.B. (2006) Podmoskovnye usad'by [Residences outside Moscow]. 3rd ed. Moscow: Russkaya usad'ba.

11. Pfeil, R. (1908) Iz vospominaniy grafa fon-Pfeylya (1881-1889) [From the memoirs of Count von Pfeil (1881-1889)]. Translated from German by A.M. Belov. Istoricheskiy vestnik. 114(10). pp. 278-288.

12. Naryshkina, E.A. (2014) Moi vospominaniya. Pod vlast'yu trekh tsarey [My Memories. Under the Rule of Three Kings]. Moscow: NLO.

13. Osin, V.M. (ed.) (2013) Dvortsovye intrigi i politicheskie avantyury. Zapiski Marii Kleynmi$\mathrm{khel}^{\prime}$ [Palace intrigues and political adventures. Notes by Maria Kleinmichel]. Moscow: AST.

14. Turkova, I.V. (n.d.) Ocherk o pustyni [Essay on the Hermitage]. [Online] Available from: http://pustin.spb.ru/index.php/istoriya-monastyrya (Accessed: 27th February 2019).

15. Clayden, A. \& Dixon, K. (2007) Woodland burial: Memorial arboretum versus natural native woodland? Mortality. 12(3). pp. 240-260. DOI: 10.1080/13576270701430700

16. Propp, V.Ya. (2001) Skazka. Epos. Pesnya [Fairy Tale. Epic. Song]. Moscow: Labirint.

17. Prusova, M.A. (2000) Realizatsiya motiva zashchity «vechnogo doma» v russkoy poezii pervoy poloviny XIX veka [The motif of "eternal home" protection in Russian poetry of the first half of the 19th century]. Kul'tura narodov Prichernomor'ya. 15. pp. 120-125.

18. Konkka, A.P. (2007) Derevo u mogily. Na kladbishchakh Severo-vostochnoy Karelii [A tree at a grave. In the cemeteries of North-Eastern Karelia]. Vestnik Sankt-Peterburgskogo universiteta. Ser. 2: Istoriya - Vestnik of St. Petersburg University. 2: History. 3. pp. 209-216. K.I.S.

19. Zamura, O. (2014) “Velikiy shalenets"': smert' i smertnist'v Get'manshchini XVIII st. Kyiv:

20. Tolstaya, S.M. \&, Tolstaya, M.N. (2003) Pogrebeniya v sadu u "goryunov" Sumskoy oblasti [Burials in the garden of the "Goryuns" in Sumy region]. Zhivaya starina. 2. pp. 10-13. 